\title{
Association between Hormonal Contraception and Injuries Induced by Human Papillomavirus in the Uterine Cervix
}

\section{Associação entre a contracepção hormonal e lesões induzidas pelo vírus do papiloma humano no colo uterino}

\author{
Lia Karina Volpato ${ }^{1}$ Isabela Ribeiro Siqueira ${ }^{1} \quad$ Rodrigo Dias Nunes $^{1}$ Anna Paula Piovezan ${ }^{1}$ \\ 1 Post-Graduation Program in Health Sciences, Universidade do Sul de \\ Santa Catarina, Palhoça, SC, Brazil \\ Rev Bras Ginecol Obstet 2018;40:196-202. \\ Address for correspondence Lia Karina Volpato, Postgraduate \\ Program in Health Sciences, Universidade do Sul de Santa Catarina \\ (UNISUL), Campus Grande Florianópolis, Av. Pedra Branca, 25, \\ Palhoça, SC, 88137-270, Brazil (e-mail: liakarina@hotmail.com).
}

\begin{abstract}
Keywords

- hormonal contraception

- human papillomavirus

- HPV

- ethinylestradiol
\end{abstract}

Resumo
Objective To evaluate the association between hormonal contraception and the appearance of human papillomavirus HPV-induced lesions in the uterine cervix of patients assisted at a school outpatient clinic - ObGyn outpatient service of the Universidade do Sul de Santa Catarina.

Methods A case-control study, with women in fertile age, performed between 2012 and 2015. A total of 101 patients with cervical lesions secondary to HPV were included in the case group, and 101 patients with normal oncotic colpocytology, in the control group. The data were analyzed through the Statistical Package for the Social Sciences (SPSS, IBM Corp. Armonk, NY, US) software, version 24.0, using the $95 \%$ confidence interval. To test the homogeneity of the proportions, the chi-square $\left(X^{2}\right)$ test was used for the qualitative variables, and the Student t-test, for the quantitative variables.

Results When comparing the occurrence of HPV lesions in users and non-users of combined oral contraceptives (COCs), the association with doses of $0.03 \mathrm{mg}$ or higher of ethinylestradiol (EE) was observed. Thus, a higher probability of developing cervical lesions induced by HPV was identified (odds ratio [OR]: 1.9 $p=0.039$ ); and when these cases were separated by the degree of the lesion, the probability of these patients presenting with lowgrade squamous intraepithelial lesion was 2.1 times higher $(p=0.036)$, but with no impact on high-grade squamous intraepithelial lesions and the occurrence of invasive cancer. No significant differences were found in the other variables analyzed.

Conclusion Although the results found in the present study suggest a higher probability of the users of combined hormonal contraceptives with a concentration higher than $0.03 \mathrm{mg}$ of EE to develop low-grade intraepithelial lesions, more studies are needed to conclude causality.

Objetivo Avaliar a associação entre a contracepção hormonal e a presença de lesões induzidas pelo vírus do papiloma humano (HPV) no colo uterino de pacientes do serviço received

December 14, 2017

accepted

March 8, 2018

published online

April 27, 2018
DOI https://doi.org/

$10.1055 / \mathrm{s}-0038-1642603$.

ISSN $0100-7203$.
Copyright $\odot 2018$ by Thieme Revinter

Publicações Ltda, Rio de Janeiro, Brazil
License terms

c) $(1) \$$ 
de ginecologia e obstetrícia do ambulatório de especialidade médicas da Universidade do Sul de Santa Catarina - AME/UNISUL.

Métodos Estudo observacional do tipo caso-controle, com mulheres no menacme, no período compreendido entre 2012 e 2015. Foram incluídas 101 pacientes com lesões cervicais secundárias ao HPV, no grupo caso, e 101 pacientes com colpocitologia oncótica normal, no grupo controle. Os dados foram analisados por meio do programa SPSS 24.0, utilizando-se o intervalo de confiança de 95\%. Para testar a homogeneidade de proporções foram utilizados o teste do qui-quadrado $\left(x^{2}\right)$ para as variáveis qualitativas e o teste $t$ de Student para as variáveis quantitativas.

Resultados Ao comparar-se a ocorrência das lesões pelo HPV em usuárias de contraceptivos orais combinados (COCs) com a em não usuárias, observou-se a associação com doses de $0.03 \mathrm{mg}$ ou superiores de etinilestradiol (EE), na qual se identificou 1.9 vezes mais probabilidade destas desenvolverem lesões cervicais induzidas pelo HPV $(p=0.039)$; ao separar-se esses casos pelo grau da lesão, a probabilidade destas

\section{Palavras-chave}

- contracepção hormonal

- vírus do papiloma humano

- HPV

- etinilestradiol pacientes apresentarem lesão cervical de baixo grau foi 2.1 vezes maior $(p=0.036)$, porém sem impacto nas lesões cervicais de alto grau e na ocorrência de câncer invasor. Não foram encontradas diferenças significativas nas outras variáveis analisadas.

Conclusão Embora os resultados encontrados no presente estudo sugiram maior probabilidade das usuárias de contraceptivo hormonal combinado, com concentração superior a 0.03 mg de EE, desenvolverem lesão cervical de baixo grau, mais estudos são necessários para concluir causalidade.

\section{Introduction}

Human papillomavirus (HPV) infection is the most common sexually transmitted disease (STD), affecting $\sim 50 \%$ of the world's population. ${ }^{1}$ It is estimated that between 75 and $80 \%$ of sexually-active individuals will acquire some subtype of HPV throughout life. ${ }^{2}$ In Brazil, the prevalence rate of HPV varies from 13.7 to $54.3 \%$, according to the population and region studied. ${ }^{3,4}$

Most genital infections are asymptomatic, but clinical forms are usually associated with low-risk oncogenic HPV and tend to be benign, whereas subclinical forms may include benign and/or malignant lesions and are usually caused by high-risk oncogenic HPV. ${ }^{5}$

Among the factors associated with the increase of HPV infection are the number of sexual partners, STD, multiparity, age of onset of sexual activity ${ }^{6,7}$ and smoking. ${ }^{2,8-11}$ There is no consensus in the literature on the association of hormonal contraceptives with the prevalence and/or persistence of cervical lesions induced by HPV. Numerous hypotheses attempt to justify the connection between the use of hormonal contraceptives and these aspects, such as the possibility of exogenous steroids acting on the HPV genome, causing mutations and the onset of cervical cancer, and the fact that progesterone increases the transcription of certain types of HPV, including HPV-16, through mediation by glucocorticoid-responsive elements that regulate virus transcription. ${ }^{12}$ Furthermore, immune responses in the female genital tract are regulated by endogenous and exogenous sex hormones, and antigen presentation, cytokine production, immunoglobulin production and transport, and induction of tolerance have all been shown to be influenced by variations in the levels of sex hormones. ${ }^{13}$ Users of combined oral contraceptives (COCs) have a decrease in immunoglobulin $A(\operatorname{Ig} A)$ and immunoglobulin $G(\operatorname{IgG})$ levels during the pause period in the cyclic schemes, thus providing a favorable environment for the appearance of HPV lesions. ${ }^{11,14-17}$

Due to the many divergences found in the literature, it is extremely important to try to clarify if there is a relationship between these factors, in order to enable physicians to provide better guidance and information to the users of this class of drugs so they may choose the best contraceptive option. Thus, this study aims to evaluate the association between hormonal contraception and the appearance of HPV-induced lesions in the uterine cervix of patients assisted at a school outpatient clinic at the Gynecology and Obstetrics Service of the Medical Ambulatory of Specialties of Universidade do Sul de Santa Catarina (AME,/USNISUL in the Portuguese acronym).

\section{Methods}

This study was based on the ethical principles of Resolution 466/12 of the Brazilian National Health Council and the Code of Ethics of the Declaration of Helsinki, and it was approved by the Research Ethics Committee of Universidade do Sul de Santa Catarina (UNISUL, in the Portuguese acronym), under the CAAE no. 17596313.9.0000.5369.

A case-control study was performed with women in fertile age at the Gynecology and Obstetrics Service of the Medical Ambulatory of Specialties (AME, in the Portuguese acronym) of UNISUL, located in the municipality of Palhoça, state of Santa Catarina, in the period between 2012 and 2015. 
Patients were selected according to the International Statistical Classification of Diseases and Related Health Problems, 10th Revision (ICD-10) on an electronic file. For the case group, the ICD-10 was used for cervical lesions (N87) and, for the control group, it was used for a gynecological revision (Z01.4). The choice of medical records was made using a systematic technique that will be explained subsequently.

In the case group, patients aged 18 to 45 years, who were submitted to cervical biopsy for alterations suggestive of HPV lesion, confirmed by anatomopathological examination, were included in the study. These patients were classified, according to the Bethesda classification, as having low-grade squamous intraepithelial lesion (LSIL), high-grade squamous intraepithelial lesion (HSIL) and invasive cancer. ${ }^{18}$ In the control group, patients within the same age range as the case group, who underwent routine gynecological evaluation, and whose oncotic colpocytology was normal, were included. In both groups, the medical records of immunocompromised patients, smokers or patients whose diagnosis of injury occurred during pregnancy, and the medical records that did not contain all the necessary information for the study, were excluded.

The sample size was calculated in the OpenEpi 2.3.1 software (Open Source Epidemiologic Statistics for Public Health, Atlanta, Georgia, EUA) using the formula for case-control studies with the following parameters: $95 \%$ confidence interval $(95 \% \mathrm{CI}), 80 \%$ test power, $60 \%$ exposed proportion between cases, $1: 1$ ratio of controls for cases and odds ratio (OR) of 2.2 for a unicaudal test. The last two parameters were used according to the article by Ajah et al, who investigated a similar outcome in a multicenter study. ${ }^{19}$ The procedure resulted in a final sample of 104 patients per group.

The extracted data was recorded in a data collection instrument specially developed for the present study. Afterwards, it was inserted in an electronic database of the Microsoft Excel (Microsoft, Redmond, WA, US) software, and exported to the Statistical Package for the Social Sciences (SPSS, IBM Corp. Armonk, NY, US) software, version 24.0, in which it was analyzed.

Qualitative variables were described by absolute and relative frequencies, while quantitative variables were described as medians, means and standard deviations for a subsequent bivariate analysis. To test the homogeneity of the proportions, the chi-square ( $\mathrm{X} 2)$ test was used for the qualitative variables, and the Student t-test, for the quantitative variables.

\section{Results}

A total of 202 medical records were included and divided into 101 cases and 101 controls. The average age of the patients with HPV cervical lesion was of $29.7 \pm 8.8$ years, while, among those without lesions, it was of $32.7 \pm 10.5$ years. This result $(p=0.687)$, which is similar to what was observed for the other sociodemographic characteristics evaluated in the study (ethnicity, marital status and level of schooling), did not differ statistically between the two groups.

Regarding the prevalence of hormonal contraceptive use in the study population, 101 patients (50\%) did not use it, while 101 patients (50\%) did. The proportion of use between groups was of $55.4 \%$ and $44.6 \%$ respectively, in the case and control groups $(p=0.157)$. The most commonly used route of administration for hormonal contraceptives in the studied population was the oral route $(90.1 \%)$, while the route of administration of $9.9 \%$ of the women was intramuscular $(p=0.283)$. There was no report of contraceptive use by the transdermal, vaginal, subcutaneous or intrauterine routes.

The average time of use of hormonal contraceptives was 5 years. There was no association between this time of use and the occurrence of cervical lesion by HPV, even when other time stratifications were evaluated. When analyzing the characteristics of time of use, route of administration (-Table 1) and formulation of hormonal contraceptives (-Table 2), compared to non-users, there was no difference between the two groups studied.

When considering the types of progesterone used and the degree of HPV lesions, 70 (69.3\%) women in the case group and 45 (44.6\%) patients in the control group used some type of progesterone, but there was no difference between users and non-users, regardless of the type of progesterone (-Table 3).

When evaluating the dose of ethinylestradiol (EE) present in the COCs, users of $0.03 \mathrm{mg} E \mathrm{EE}$ had a 1.9 -fold increased risk of developing cervical lesions induced by HPV when compared with non-users of contraceptives $(p=0.039)$ (-Table 4); in these cases, the risk of developing LSIL was 2.1 times higher, but with no impact on HSIL and on the occurrence of invasive cancer (-Table 5).

\section{Discussion}

The present study demonstrated, for the first time in the Brazilian population, the association between the use of oral

Table 1 Association between contraceptive route of administration and HPV lesions compared to non-users in the study patients

\begin{tabular}{|l|l|l|l|l|l|}
\hline Route of Administration & $\begin{array}{l}\text { Case } \\
\mathbf{n}(\%)\end{array}$ & $\begin{array}{l}\text { Control } \\
\mathbf{n}(\%)\end{array}$ & $\begin{array}{l}\text { Total } \\
\mathbf{n}(\%)\end{array}$ & $p$-value & OR (95\%Cl) \\
\hline Non-user & $45(44.5)$ & $56(55.4)$ & $101(50.0)$ & - & 1 \\
\hline User & & & & & \\
\hline Oral & $51(50.5)$ & $40(86.9)$ & $91(45.0)$ & 0.283 & $0.6443(0.3648-1.1378)$ \\
\hline Intramuscular & $5(5.0)$ & $5(5.0)$ & $10(5.0)$ & 0.715 & $0.8214(0.2240-3.0126)$ \\
\hline
\end{tabular}

Abbreviations: $95 \% \mathrm{Cl}$, 95\% confidence interval; OR, odds ratio. 
Table 2 Association between contraceptive composition and HPV lesions compared to non-users in the study patients

\begin{tabular}{|l|l|l|l|l|l|}
\hline Composition & $\begin{array}{l}\text { Case } \\
\mathbf{n}(\%)\end{array}$ & $\begin{array}{l}\text { Control } \\
\mathbf{n}(\%)\end{array}$ & $\begin{array}{l}\text { Total } \\
\mathbf{n}(\%)\end{array}$ & p-value & OR (95\%CI) \\
\hline Non-user & $45(44.5)$ & $56(55.4)$ & $101(50.0)$ & - & 1 \\
\hline User & & & & & \\
\hline EE + associations & $48(47.6)$ & $39(39.6)$ & $86(43.1)$ & 0.147 & $1.5316(0.8604-2.7263)$ \\
\hline E2 + associations & $6(5.9)$ & $4(4)$ & $10(4.9)$ & 0.355 & $1.8667(0.4964-7.0201)$ \\
\hline DMPA & $1(1.0)$ & - & $1(0.5)$ & 0.615 & $0.2743(0.0109-6.8944)$ \\
\hline DSG & $1(1.0)$ & $2(2.0)$ & $3(1.5)$ & 0.452 & $2.4643(0.2479-24.4951)$ \\
\hline
\end{tabular}

Abbreviations: 95\% Cl, 95\% confidence interval; DSG, desogestrel; DMPA, depot medroxyprogesterone acetate; EE, ethynilestradiol; E2, estradiol; OR, odds ratio.

Table 3 Association between the type of progesterone present in hormonal contraceptives and the degree of HPV lesions compared to non-users in the study patients

\begin{tabular}{|c|c|c|c|c|c|}
\hline Progesterone & $\begin{array}{l}\text { Case } \\
\text { n (\%) }\end{array}$ & $\begin{array}{l}\text { Control } \\
\text { n (\%) }\end{array}$ & $\begin{array}{l}\text { Total } \\
\text { n (\%) }\end{array}$ & $p$-value & OR $(95 \% \mathrm{Cl})$ \\
\hline \multicolumn{6}{|c|}{$\operatorname{LSIL}(n=70 / 98)$} \\
\hline Non-user & $31(31.6)$ & $56(57.1)$ & $87(51.8)$ & - & 1 \\
\hline \multicolumn{6}{|l|}{ User } \\
\hline CPA & $6(8.6)$ & $7(7.1)$ & $15(8.9)$ & 0.466 & $1.5484(0.4780-5.0160)$ \\
\hline DSG & $22(31.4)$ & $19(19.4)$ & $41(24.4)$ & 0.055 & $2.0917(0.9836-4.4482)$ \\
\hline DHPA & $2(2.9)$ & $1(1.0)$ & $3(1.8)$ & 0.302 & $3.6129(0.3148-41.4622)$ \\
\hline DMPA & $1(1.4)$ & - & $1(0.6)$ & 0.307 & $5.3810(0.2128-136.0563)$ \\
\hline DRSP & $3(4.3)$ & $1(1.0)$ & $4(2.4)$ & 0.150 & $5.4194(0.5404-54.3438)$ \\
\hline GST & $3(4.3)$ & $10(10.2)$ & $13(7.7)$ & 0.378 & $0.5419(0.1387-2.1174)$ \\
\hline LNG & $1(1.4)$ & $4(4.1)$ & $5(3.0)$ & 0.485 & $0.4516(0.0483-4.2203)$ \\
\hline NET-EN & $1(1.4)$ & - & $1(0.6)$ & 0.307 & $5.3810(0.2128-136.0563)$ \\
\hline \multicolumn{6}{|c|}{ HSIL $(n=28 / 98)$} \\
\hline Non-user & $12(42.8)$ & $56(57.1)$ & $68(54.0)$ & - & 1 \\
\hline \multicolumn{6}{|l|}{ User } \\
\hline CPA & $6(21.4)$ & $7(7.1)$ & $15(11.9)$ & 0.070 & $3.3333(0.9029-12.3056)$ \\
\hline DSG & $4(14.3)$ & $19(19.4)$ & $23(18.2)$ & 0.977 & $0.9825(0.2827-3.4138)$ \\
\hline DHPA & - & $1(1.0)$ & $1(0.8)$ & 0.805 & $1.5067(0.0579-39.1998)$ \\
\hline DRSP & $1(3.6)$ & $1(1.0)$ & $2(1.6)$ & 0.287 & $4.6667(0.2723-79.9627)$ \\
\hline GST & $1(3.6)$ & $10(10.2)$ & $11(8.7)$ & 0.486 & $0.4667(0.0545-3.9988)$ \\
\hline LNG & $1(3.6)$ & $4(4.1)$ & $5(4.0)$ & 0.894 & $1.1667(0.1195-11.3870)$ \\
\hline NET-EN & $3(10.7)$ & - & $3(2.4)$ & 0.776 & $0.6457(0.0313-13.3099)$ \\
\hline \multicolumn{6}{|c|}{ Invasive cancer $(n=3 / 98)$} \\
\hline Non-user & $2(66.7)$ & $56(57.1)$ & $58(57.4)$ & - & 1 \\
\hline \multicolumn{6}{|l|}{ User } \\
\hline CPA & - & $7(7.1)$ & $7(6.9)$ & 0.797 & $1.5067(0.0658-34.4808)$ \\
\hline DSG & $1(33.3)$ & $19(19.4)$ & $20(19.8)$ & 0.757 & $1.4737(0.1264-17.1847)$ \\
\hline DHPA & - & $1(1.0)$ & $1(1.0)$ & 0.250 & $7.5333(0.2410-235.4646)$ \\
\hline DRSP & - & $1(1.0)$ & $1(1.0)$ & 0.250 & $7.5333(0.2410-235.4646)$ \\
\hline GST & - & $10(10.2)$ & $10(9.9)$ & 0.963 & $1.0762(0.0481-24.0580)$ \\
\hline LNG & - & $4(4.1)$ & $4(4.0)$ & 0.570 & $2.5111(0.1039-60.6610)$ \\
\hline
\end{tabular}

Abbreviations: $95 \% \mathrm{Cl}$, 95\% confidence interval; CPA, cyproterone acetate; DHPA, dihydroxyprogesterone acetate; DMPA, depot medroxyprogesterone acetate; DRSP, drospirenone; DSG, desogestrel; GST, gestodene; HSIL, high-grade squamous intraepithelial lesion; LNG, levonorgestrel; LSIL, low-grade squamous intraepithelial lesion; NET-EN, norethisterone enantate; OR, odds ratio. 
Table 4 Association between doses of ethinylestradiol present in oral combined hormonal contraceptives and HPV lesions compared to non-users in the study patients

\begin{tabular}{|l|l|l|l|l|l|}
\hline EE Dose $(\mathbf{m g})$ & Case $\mathbf{n}=\mathbf{9 3}$ & Control $\mathbf{n}=\mathbf{9 5}$ & Total $\mathbf{n}=\mathbf{1 8 8}$ & $\mathbf{p}$-value & OR $\mathbf{( 9 5 \% C l )}$ \\
\hline Non-user & $45(48.0 \%)$ & $56(58.9 \%)$ & $101(53.7 \%)$ & & 1 \\
\hline User & & & & & \\
\hline$\geq 0.03 \mathrm{mg}$ & $38(40.8 \%)$ & $24(25.3 \%)$ & $62(33.0 \%)$ & 0.039 & $1.9704(1.0345-3.7529)$ \\
\hline$\leq 0.02 \mathrm{mg}$ & $10(10.7 \%)$ & $15(15.8 \%)$ & $25(13.3 \%)$ & 0.681 & $0.8296(0.4829-2.0265)$ \\
\hline
\end{tabular}

Abbreviation: 95\% Cl, 95\% confidence interval; EE, ethinylestradiol; OR, odds ratio.

Table 5 Association between doses of ethinylestradiol present in oral combined hormonal contraceptives and the degree of HPV lesions compared to non-users in the study patients

\begin{tabular}{|l|l|l|l|l|l|l|}
\hline EE Dose $(\mathrm{mg})$ & Case $\mathbf{n}(\%)$ & Control $\mathbf{n}(\%)$ & Total $\mathbf{n}(\%)$ & $p$-value & OR (95\%Cl) \\
\hline LSIL $(n=70 / 95)$ & $31(44.3)$ & $56(58.9)$ & $87(52.7)$ & - & 1 \\
\hline Non-user & & & & & \\
\hline User & $28(40.0)$ & $24(25.3)$ & $52(31.5)$ & 0.036 & $2.1075(1.0467-4.2434)$ \\
\hline$\geq 0.03$ & $11(15.7)$ & $15(15.8)$ & $26(15.3)$ & 0.537 & $1.3247(0.5423-3.2363)$ \\
\hline$\leq 0.02$ & $12(42.9)$ & $56(58.9)$ & $68(55.3)$ & - & 1 \\
\hline HSIL $(n=28 / 95)$ & & & & \\
\hline Non-user & $10(35.7)$ & $24(25.3)$ & $34(27.6)$ & 0.177 & $1.9444(0.7401-5.1083)$ \\
\hline User & $6(21.4)$ & $15(15.8)$ & $21(17.1)$ & 0.280 & $1.8667(0.6008-5.7995)$ \\
\hline$\geq 0.03$ & $2(66.7)$ & $56(58.9)$ & $58(59.2)$ & - & 1 \\
\hline$\leq 0.02$ & - & - & - & - & - \\
\hline Invasive cancer $(n=3 / 95)$ & $24(25.3)$ & $24(24.5)$ & 0.621 & $0.46120(0.0213-9.9676)$ \\
\hline Non-user & - & $15(15.8)$ & $16(13.3)$ & 0.620 & $1.8667(0.1583-22.0070)$ \\
\hline User & $1(33.4)$ &
\end{tabular}

Abbreviations: $95 \% \mathrm{Cl}$, 95\% confidence interval; EE, ethinylestradiol; HSIL, high-grade squamous intraepithelial lesion; LSIL, low-grade squamous intraepithelial lesion; OR, odds ratio.

hormonal contraceptives based on EE at the dose of $0.03 \mathrm{mg}$ and the appearance of HPV-induced LSIL in the uterine cervix.

When analyzing the sociodemographic variables of the patients in the present study, no characteristic was considered significant either for the development or non-development of the lesions. These findings were similar to those described in 2016 by Abouzeid and El-Agwany, ${ }^{10}$ who recorded, in a casecontrol study with 250 women, that there was no significant statistical difference in age, marital status or parity.

Other studies evaluated the association of cervical lesions with sociodemographic variables not investigated in the present study. Among the women younger than 35 years of age, women who lived in rural areas, and women with no fixed partners, women with a lower educational level and multiparous women, a greater probability of developing cervical neoplasm was observed. ${ }^{20}$ Another study aimed at determining the demographic and behavioral factors associated with HPV positivity, a prevalence of $25.3 \%$ of HPV lesions was identified in patients aged between 31 and 35 years. ${ }^{21}$ In 2010, when investigating the short-term persistence of HPV infection among 2,408 women with low-grade cervical lesions or other cytological abnormalities, Maucort et al found a greater probability of HPV lesion persistence in white women aged between 20 and 29-years. ${ }^{5}$

In addition, there was no difference between the groups when considering the characteristics of the patients observed in the present study, regarding the prevalence of use, route of administration and time of use of hormonal contraceptives. Finally, no association was found between these characteristics of the use of hormonal contraception and the presence of cervical lesions, as well as no significant difference between the case and control groups. These findings are similar to those of Westreich et $\mathrm{al}^{21}$ in 2014, who analyzed the impact of the use of depot medroxyprogesterone (DMPA), norethisterone enanthate (NET-EN) and COCs separately, on the incidence and progression of cervical lesions, without finding significant differences. Similarly, Binesh et $\mathrm{al}^{22}$ in 2013, in a cross-sectional study, found no association between COC consumption and changes in cervical cytology, agreeing with the findings of Sammarco et al, ${ }^{8}$ 
in 2013, when studying the persistence and clearance of HPV in users of COCs, after evaluating and controlling possible confounding factors.

In contrast, in 2011, Marks et $\mathrm{al}^{23}$ identified an association between the appearance of new HPV lesions in women using COCs, while Mitchell et al, ${ }^{20}$ in 2014, and Jensen et al, ${ }^{24}$ in 2013, demonstrated that the use of any hormonal contraceptive increases the probability of the persistence of HPV carcinogenic viruses when compared with non-users, and MaucourtBouch et al, in 2010, observed a slight increase in the risk of persistent lesions in injectable contraceptive users. ${ }^{5}$

Regarding the time of use of contraceptives, there was no statistical significance in the present study, a finding similar to those of the studies by Westreich et $\mathrm{al}^{22}$ in 2014, and Green et al, ${ }^{25}$ in 2003. Watson-Jones et al, ${ }^{6}$ in 2013 , suggested that the use of hormonal contraceptives, both oral and intramuscular, for less than four years, would serve as a protective factor against HPV lesions when compared to condom use.

On the other hand, Roura et al, in 2016, identified a strong association between the time of COC use and the risk of developing HSIL and invasive cancer. ${ }^{9}$ Marks et al, ${ }^{2}$ in 2011, identified that current COC use for more than 6 years is associated with an increased risk of developing persistent HPV infections; and Brinton, ${ }^{26}$ in 1991, suggested that 10 years of COC use could present an increased risk of developing cervical cancer, which are findings similar to those of other studies with variable research designs that evaluated the long-term use of contraceptives. ${ }^{19,27}$

In the present study, no association was found between HPV lesions and the progesterone types present in the contraceptives, either alone or associated with EE. Abouzeid and El-Agwany ${ }^{10}$ reached similar findings in 2016 in a casecontrol study including 200 users of contraceptives containing progesterone alone and 50 non-hormonal contraceptive users, data corroborated by Darwish et $\mathrm{al}^{28}$ in 2004 . Contradicting these findings, in 1990 , Herrero et al $^{29}$ demonstrated that women receiving DMPA had a high risk of developing cervical cancer, but this result was significant only in those patients who had used it for more than five years, which was the median time of hormone use in the present study.

When comparing hormonal contraceptive types and associating them with the HPV lesions, a statistical significance was not evidenced, but when comparing only the doses of EE, separated in doses of $0.03 \mathrm{mg}$ and $0.02 \mathrm{mg}$, there was a significant association. Patients taking higher doses of estrogen are more likely to develop HPV-induced lesions, especially LSIL. This fact could be justified by the stimulation of a cervical ectopy secondary to higher concentrations of estrogen, ${ }^{30}$ besides altering the immune system and inducing an increased concentration and activity of pro-inflammatory cytokines, ${ }^{31}$ facilitating the development of these lesions.

No studies have been found to systematically assess and compare the dose of EE present in COCs and its association with HPV-induced lesions. In 2012, Aksoy et al, ${ }^{32}$ when evaluating the effect of EE $0.30 \mathrm{mg}+$ drospirenone $3 \mathrm{mg}$ on the cervical mucus, observed a statistically significant increase in mucoprotein 2 (MUC2) levels, suggesting that this is related to the efficacy of COCs, and also speculating that the
MUC2 increase induced by the hormonal contraceptive may be the mechanism responsible for the cervical carcinogenesis induced by this method, although they consider that largescale longitudinal studies are necessary to confirm these findings. ${ }^{32}$ Mitrani-Rosenbaum et al $^{33}$ (1989) and Gadducci et $\mathrm{al}^{34}$ (2011) have demonstrated that both estrogen and progesterone can affect cervical cells by HPV mRNA transcription and by integrating it into the host DNA. In addition, sex steroids could increase the expression of HPV E6 and E7 genes, leading to apoptosis failure and promoting carcinogenesis. However, Webster et $\mathrm{al}^{35}$ (2001) failed to demonstrate that estrogen or progesterone could interfere with HPV cellular apoptosis, and Harris et $\mathrm{al}^{36}$ (2009) found that recent use of concentrations of $\mathrm{EE}>0.03 \mathrm{mg}$ for more than 2 years is not associated with high-grade cervical lesions.

The present study had some limitations, which were related but not restricted to the convenience sampling, the number of cases raised, and the design adopted. The evaluation of confounding factors was not possible because the study is retrospective and based on data analysis of medical records. It is possible that the inconsistencies reported in the association between hormonal contraception and cervical lesions caused by HPV may be related in part to these confounding risk factors, including lifestyle, sexual behavior and HPV oncogenic type, which are very difficult to control.

\section{Conclusion}

Although the results found in the present study suggest that the users of COCs with concentrations of $\mathrm{EE}>0.03 \mathrm{mg}$ could develop LSIL, a cause-effect relationship could not be determined due to the design of the study, and more studies are needed to conclude causality. However, this finding seems even more relevant if we consider the median time of 5 years of use of COCs with concentrations of EE $>0.03 \mathrm{mg}$, as well as the average age of the users $(27.8 \pm 6.4$ years $)$, deserving professional attention regarding the orientation and follow-up of these women. The mechanisms involved in the persistence and incidence of HPV lesions are far from being clarified, and new studies are needed to elucidate better approaches regarding the type of contraception, route of administration and hormonal doses that are not associated with HPV-induced lesions.

\section{Contributors}

Volpato L. K., Siqueira I. R., Nunes R. D. and Piovezan A. P. contributed with the project and data interpretation, writing of the article, critical review of the intellectual content, and final approval of the version to be published.

\section{Conflicts of Interest}

The authors have no conflicts of interest to disclose.

\section{References}

1 Baseman JG, Koutsky LA. The epidemiology of human papillomavirus infections. J Clin Virol 2005;32(Suppl 1):S16-S24. Doi: 10.1016/j.jcv.2004.12.008

2 Marks M, Gravitt PE, Gupta SB, et al. Combined oral contraceptive use increases HPV persistence but not new HPV detection in a 
cohort of women from Thailand. J Infect Dis 2011;204(10): 1505-1513. Doi: 10.1093/infdis/jir560

3 Coser J, Boeira TdaR, Wolf JM, Cerbaro K, Simon D, Lunge VR. Cervical human papillomavirus infection and persistence: a clinic-based study in the countryside from South Brazil. Braz J Infect Dis 2016;20(01):61-68. Doi: 10.1016/j.bjid.2015.10.008

4 Silva C, Almeida ECS, Côbo EdeC, Zeferino VFM, Murta EFC, Etchebehere RM. A retrospective study on cervical intraepithelial lesions of low-grade and undetermined significance: evolution, associated factors and cytohistological correlation. Sao Paulo Med J 2014;132(02):92-96. Doi: 10.1590/1516-3180.2014.1322579

5 Maucort-Boulch D, Plummer M, Castle PE, et al. Predictors of human papillomavirus persistence among women with equivocal or mildly abnormal cytology. Int J Cancer 2010;126(03):684-691. Doi: $10.1002 /$ ijc.24752

6 Watson-Jones D, Baisley K, Brown J, et al. High prevalence and incidence of human papillomavirus in a cohort of healthy young African female subjects. Sex Transm Infect 2013;89(05):358-365. Doi: 10.1136/sextrans-2012-050685

7 Borruto F, Comparetto C. Human papillomavirus: natural history of a viral infection in the genesis of a cancer. In: Borruto F, de Ridder $\mathrm{M}$, eds. HPV and Cervical Cancer: Achievements in Prevention and Future Prospects. New York, NY: Springer-Verlag; 2012:7-43

8 Sammarco ML, Del Riccio I, Tamburro M, Grasso GM, Ripabelli G. Type-specific persistence and associated risk factors of human papillomavirus infections in women living in central Italy. Eur J Obstet Gynecol Reprod Biol 2013;168(02):222-226. Doi: 10.1016/j. ejogrb.2013.01.012

9 Roura E, Travier N, Waterboer T, et al. The influence of hormonal factors on the risk of developing cervical cancer and pre-cancer: results from the EPIC cohort. PLoS One 2016;11(01):e0147029. Doi: 10.1371/journal.pone.0147029

10 Abouzeid ZS, El-Agwany AS. Papanicolaou smear interpretation with progestin-only hormonal birth control methods. J Reprod Contracept 2016;27:25-40. Doi: 10.7669/j.issn.1001-7844.2016.01.0025

11 Ghanem KG, Datta SD, Unger ER, et al. The association of current hormonal contraceptive use with type-specific HPV detection. Sex Transm Infect 2011;87(05):385-388. Doi: 10.1136/sextrans2011-050005

12 Nayar R, Wilbur DC. The Pap Test and Bethesda 2014: the reports of my demise have been greatly exaggerated. J Am Soc Cytopathol 2015;4:170-180. Doi: 10.1016/j.jasc.2015.03.003

13 Brotman RM, Ravel J, Bavoil PM, Gravitt PE, Ghanem KG. Microbiome, sex hormones, and immune responses in the reproductive tract: challenges for vaccine development against sexually transmitted infections. Vaccine 2014;32(14):1543-1552. Doi: 10.1016/j.vaccine.2013.10.010

14 Zandberg DP, Bhargava R, Badin S, Cullen KJ. The role of human papillomavirus in nongenital cancers. CA Cancer J Clin 2013;63 (01):57-81. Doi: 10.3322/caac.21167

15 Franklin RD, Kutteh WH. Characterization of immunoglobulins and cytokines in human cervical mucus: influence of exogenous and endogenous hormones. J Reprod Immunol 1999;42(02):93-106

16 Safaeian M, Falk RT, Rodriguez AC, et al. Factors associated with fluctuations in IgA and IgG levels at the cervix during the menstrual cycle. J Infect Dis 2009;199(03):455-463. Doi: 10.1086/596060

17 Nardelli-Haefliger D, Wirthner D, Schiller JT, et al. Specific antibody levels at the cervix during the menstrual cycle of women vaccinated with human papillomavirus 16 virus-like particles. J Natl Cancer Inst 2003;95(15):1128-1137

18 Moreno V, Bosch FX, Muñoz N, et al; International Agency for Research on Cancer. Multicentric Cervical Cancer Study Group. Effect of oral contraceptives on risk of cervical cancer in women with human papillomavirus infection: the IARC multicentric case-control study. Lancet 2002;359(9312):1085-1092. Doi: $10.1016 /$ S0140-6736(02)08150-3
19 Ajah LO, Chigbu CO, Ozumba BC, Oguanuo TC, Ezeonu PO. Association of intrauterine device (IUD) and cervical neoplasia - A study in a poor Nigerian population. J Clin Diagn Res 2016;10(06): QC05-QC08. Doi: 10.7860/JCDR/2016/18328.8049

20 Mitchell SM, Sekikubo M, Biryabarema C, et al. Factors associated with high-risk HPV positivity in a low-resource setting in subSaharan Africa. Am J Obstet Gynecol 2014;210(01):81.e1-81.e7. Doi: 10.1016/j.ajog.2013.08.038

21 Westreich D, Jamal N, Smith JS, et al. Injectable and oral contraception and the incidence and progression of cervical disease in HIV-infected women in South Africa. Contraception 2014;89(04): 286-291. Doi: 10.1016/j.contraception.2013.12.011

22 Binesh F, Akhavan A, Pirdehghan A, Davoodi M. Does oral contraceptive pill increase the risk of abnormal Pap smear? Iran J Reprod Med 2013;11(09):761-766

23 Marks M, Gravitt PE, Gupta SB, et al. The association of hormonal contraceptive use and HPV prevalence. Int J Cancer 2011;128(12): 2962-2970. Doi: 10.1002/ijc.25628

24 Jensen KE, Schmiedel S, Norrild B, Frederiksen K, Iftner T, Kjaer SK. Parity as a cofactor for high-grade cervical disease among women with persistent human papillomavirus infection: a 13-year followup. Br J Cancer 2013;108(01):234-239. Doi: 10.1038/bjc.2012.513

25 Green J, Berrington de Gonzalez A, Smith JS, et al. Human papillomavirus infection and use of oral contraceptives. $\mathrm{Br} \mathrm{J}$ Cancer 2003;88(11):1713-1720. Doi: 10.1038/sj.bjc.6600971

26 Brinton LA. Oral contraceptives and cervical neoplasia. Contraception 1991;43(06):581-595. Doi: 10.1016/0010-7824(91)90005-Z

27 La Vecchia C, Boccia S. Oral contraceptives, human papillomavirus and cervical cancer. Eur J Cancer Prev 2014;23(02):110-112. Doi: 10.1097/CEJ.0000000000000000

28 Darwish A, Labeeb S, Galal M, Rashad H, Hassan S. Cervical changes associated with progestagen-only contraceptives: a team approach. Contraception 2004;69(02):121-127. Doi: 10.1016/j.contraception.2003.09.010

29 Herrero R, Brinton LA, Reeves WC, et al. Injectable contraceptives and risk of invasive cervical cancer: evidence of an association. Int J Cancer 1990;46(01):5-7. Doi: 10.1002/ijc.2910460103

30 Parellada CI, Campaner AB. Contracepção e terapia hormonal em mulheres infectadas pelo HPV. Rev Bras Patol Trato Genit Inf 2011; 1:16-19

31 Marks MA, Klein SL, Gravitt PE. Hormonal contraception and HPV: a tale of differing and overlapping mechanisms. Open Access J Contracept. 2011;2:161-174. Doi: 10.2147/OAJC.S17404

32 Aksoy M, Guven S, Tosun I, Aydın F, Kart C. The effect of ethinyl estradiol and drospirenone-containing oral contraceptives upon mucoprotein content of cervical mucus. Eur J Obstet Gynecol Reprod Biol 2012;164(01):40-43. Doi: 10.1016/ j.ejogrb.2012.05.002

33 Mitrani-Rosenbaum S, Tsvieli R, Tur-Kaspa R. Oestrogen stimulates differential transcription of human papillomavirus type 16 in SiHa cervical carcinoma cells. J Gen Virol 1989;70(Pt 8):2227-2232. Doi: 10.1099/0022-1317-70-8-2227

34 Gadducci A, Barsotti C, Cosio S, Domenici L, Riccardo Genazzani A. Smoking habit, immune suppression, oral contraceptive use, and hormone replacement therapy use and cervical carcinogenesis: a review of the literature. Gynecol Endocrinol 2011;27(08): 597-604. Doi: 10.3109/09513590.2011.558953

35 Webster K, Taylor A, Gaston K. Oestrogen and progesterone increase the levels of apoptosis induced by the human papillomavirus type 16 E2 and E7 proteins. J Gen Virol 2001;82 (Pt 1):201-213. Doi: 10.1099/0022-1317-82-1-201

36 Harris TG, Miller L, Kulasingam SL, et al. Depot-medroxyprogesterone acetate and combined oral contraceptive use and cervical neoplasia among women with oncogenic human papillomavirus infection. Am J Obstet Gynecol 2009;200(05):489.e1-489.e8. Doi: 10.1016/j.ajog.2009.01.030 